\title{
Mechanism of Growth Inhibition of Human Cancer Cells by Conjugated Eicosapentaenoic Acid, an Inhibitor of DNA Polymerase and Topoisomerase
}

\author{
Yuko Yonezawa ${ }^{1}$, Hiromi Yoshida ${ }^{1,2}$ and Yoshiyuki Mizushina ${ }^{1,2, *}$ \\ 1 Laboratory of Food \& Nutritional Sciences, Department of Nutritional Science, Kobe-Gakuin \\ University, Nishi-ku, Kobe, Hyogo 651-2180, Japan \\ E-mails: yonezawa@nutr.kobegakuin.ac.jp (Y.Y.); E-mail: yoshida@nutr.kobegakuin.ac.jp (H.Y.) \\ 2 Cooperative Research Center of Life Sciences, Kobe-Gakuin University, Nishi-ku, Kobe, Hyogo \\ 651-2180, Japan
}
* Author to whom correspondence should be addressed; Tel.: +81-78-974-1551 (ext. 3232), Fax: +81- 78-974-5689; E-mail: mizushin@nutr.kobegakuin.ac.jp (Y.M.)

Received: 12 November 2007; in revised form: 27 November 2007 / Accepted: 28 November 2007 / Published: 7 December 2007

\begin{abstract}
DNA topoisomerases (topos) and DNA polymerases (pols) are involved in many aspects of DNA metabolism such as replication reactions. We found that long chain unsaturated fatty acids such as polyunsaturated fatty acids (PUFA) (i.e., eicosapentaenoic acid (EPA) and docosahexaenoic acid (DHA)) inhibited the activities of eukaryotic pols and topos in vitro, and the inhibitory effect of conjugated fatty acids converted from EPA and DHA (cEPA and cDHA) on pols and topos was stronger than that of normal EPA and DHA. cEPA and cDHA did not affect the activities of plant and prokaryotic pols or other DNA metabolic enzymes tested. cEPA was a stronger inhibitor than cDHA with $\mathrm{IC}_{50}$ values for mammalian pols and human topos of $11.0-31.8$ and $0.5-2.5 \mu \mathrm{M}$, respectively. cEPA inhibited the proliferation of two human leukemia cell lines, NALM-6, which is a p53-wild type, and HL-60, which is a p53-null mutant, and the inhibitory effect was stronger than that of normal EPA. In both cell lines, cEPA arrested in the G1 phase, and increased cyclin E protein levels, indicating that it blocks the primary step of in vivo DNA replication by inhibiting the activity of replicative pols rather than topos. DNA replication-related proteins, such as RPA70, ATR and phosphorylated-Chk1/2, were increased by cEPA treatment in the cell lines, suggesting that cEPA led to DNA replication fork stress inhibiting the activities of pols and topos, and the ATR-dependent DNA damage response
\end{abstract}


pathway could respond to the inhibitor of DNA replication. The compound induced cell apoptosis through both p53-dependent and p53-independent pathways in cell lines NALM-6 and HL-60, respectively. These results suggested the therapeutic potential of conjugated PUFA, such as cEPA, as a leading anti-cancer compound that inhibited pols and topos activities.

Keywords: conjugated eicosapentaenoic acid (cEPA), DNA polymerase, DNA topoisomerase, enzyme inhibitor, DNA replication, cell proliferation, cell cycle arrest, p53, apoptosis.

\section{Introduction}

Both DNA polymerases (pols) and DNA topoisomerases (topos) have recently emerged as important cellular targets for chemical intervention in the development of anti-cancer agents. Pol catalyzes the addition of deoxyribonucleotides to the 3'-hydroxyl terminus of primed double-stranded DNA (dsDNA) molecules [1], and topo catalyzes the concerted breaking and rejoining of DNA strands and is involved in producing the necessary topological and conformational changes in DNA [1, 2]. Therefore, there are no enzymatic similarities between the two enzymes, although they are both critical to many cellular processes such as DNA replication, repair and recombination, and may act in harmony with each other.

We have screened for inhibitors of pols [3, 4], and found that mammalian pols $\alpha$ and $\beta$ are inhibited by linear-chain fatty acids with the following characteristics: a hydrocarbon chain containing 18 or more carbons, a free carboxyl end, and double bonds with the cis-configuration, n-3 polyunsaturated fatty acid (PUFA) having the strongest inhibitory effect of any fatty acid tested $[4,5]$. These fatty acids also inhibit the activities of human topos I and II [6]. Epidemiological data indicate that consumption of fish oil rich in PUFA correlates with a reduced incidence of colon cancer [7]. Experimental studies indicate that fish oil plays a protective role in mice [8] and rats [9] and that perilla oil rich in n-3 PUFA ( $\alpha$-linolenic acid) inhibits colon carcinogenesis in rats [10]. n-3 PUFAs seem to be particularly important in the inhibition of colon carcinogenesis. Eicosapentaenoic acid (EPA; 5Z8Z11Z14Z17Z-20:5) and docosahexaenoic acid (DHA; 4Z7Z10Z13Z16Z19Z-22:6), both of which are n-3 PUFAs, exert significant inhibitory effects on colon carcinoma cell growth at the primary site and metastases $[11,12]$. However, it is unclear which class of n-3 PUFA is more potent in suppressing colon carcinogenesis.

Conjugated fatty acids are positional and geometrical isomers with several conjugated double bonds. One of these, conjugated linoleic acid (cLA), is found in meats from ruminants and in dairy products [13] and reportedly reduces colon cancer risk in rats [14]. cLA also reportedly inhibits growth of human colon cancer cells in culture $[15,16]$. As linoleic acid, an n-6 PUFA, accelerates the growth of colon cancer cells [12], the opposite effect of cLA is of particular interest. As n-3 PUFAs have been shown to have anticarcinogenic activity, conjugated fatty acids converted from n-3 PUFAs may show higher tumor-inhibiting activity than cLA or n-3 PUFAs themselves. Fatty acids with conjugated double bonds exist in nature: seaweeds, such as red and green algae, contain highly n-3 
unsaturated conjugated fatty acids, i.e., conjugated EPA (cEPA; 5Z7E9E14Z17Z-20:5), bosseopentaenoic acid (5Z8Z10E12E14Z-20:5) and stellaheptaenoic acid (4Z7Z9E11E13Z16Z19Z22:7) $[17,18]$.

In this review, we realize the importance of the two classes of n-3 PUFA; EPA and DHA, normal and conjugated, and the inhibitory effect of cEPA on both pols and topos is stronger than that of cDHA. Thus, cEPA seems to be an ideal model for the study not only of the molecular mechanisms that inhibit pols and topos activities for the development of new anticancer drugs, but also of cellular proliferation processes such as DNA replication and cell cycle. Furthermore, we demonstrate that cEPA induces cell cycle arrest at G1 phase arrest and apoptosis mediated by both p53-dependent and p53-independent pathways, and suggest that the cell cycle is tightly regulated by DNA damageresponse proteins including the ATR-Chk1/2 pathway.

\section{Preparation of conjugated PUFA by alkaline treatment}

Conjugated PUFA, such as cEPA and cDHA, were prepared by alkaline treatment following the AOAC method with slight modifications [19]. Potassium hydroxide at a concentration of 6.6 or $21 \%$ $(\mathrm{w} / \mathrm{w})$ in ethylene glycol was prepared and the $\mathrm{KOH}$ solution was bubbled for 5 min with nitrogen gas. Ten milligrams of EPA or DHA was added to $1 \mathrm{ml}$ of the $6.6 \%$ or $21 \% \mathrm{KOH}$ solution in a test tube (10 $\mathrm{ml}$ volume). The mixture was bubbled with nitrogen gas and then screw-capped and allowed to stand for 5 or $10 \mathrm{~min}$ at $180{ }^{\circ} \mathrm{C}$. The reaction mixture was cooled, and $1 \mathrm{ml}$ of methanol was added. The mixture was acidified to below pH 2 with $2 \mathrm{ml}$ of $6 \mathrm{~N} \mathrm{HCl}$. After dilution with $2 \mathrm{ml}$ of distilled water, the conjugated fatty acid was extracted with $5 \mathrm{ml}$ of hexane. The hexane extract was then washed with $3 \mathrm{ml}$ of $30 \%$ methanol and with $3 \mathrm{ml}$ of distilled water before being evaporated under a nitrogen gas stream. The conjugated fatty acids were stored at $-20{ }^{\circ} \mathrm{C}$ after being purged with nitrogen gas. UV/VIS spectrophotometric analysis of the conjugated fatty acid was performed with a Shimadzu UV-2400PC. Spectrophotometric readings confirmed the conjugation of fatty acids of pentaene (345 $\mathrm{nm})$ and hexaene $(375 \mathrm{~nm})[19,20]$. The mainly isomer of the produced cEPA was 5Z7E9E14Z17Z. The conjugated PUFA and normal PUFA were dissolved in dimethyl sulfoxide (DMSO) at various concentrations and sonicated for $30 \mathrm{sec}$.

\section{DNA polymerase inhibition by normal and conjugated PUFA}

\subsection{DNA polymerase}

Eukaryotic cells reportedly contain three replicative DNA polymerases (pols $\alpha, \delta$, and $\varepsilon$ ), mitochondrial DNA polymerase (pol $\gamma$ ) and at least eleven repair types of DNA polymerases (pols $\beta, \delta, \varepsilon, \zeta, \eta, \theta, \kappa, \lambda, \mu, \sigma, \operatorname{REV} 1)[1,21]$.

pol $\alpha$ was purified from calf thymus by immuno-affinity column chromatography as described previously [22]. Recombinant rat pol $\beta$ was purified from E. coli JMp $\beta 5$ as described by Date et al. [23]. The human pol $\gamma$ catalytic gene was cloned into pFastBac. Histidine-tagged enzymes were expressed using the BAC-TO-BAC HT Baculovirus Expression System according to the supplier's manual (LIFE TECHNOLOGIES, Maryland, USA) and purified using ProBoundresin (Invitrogen Japan, Tokyo Japan) [24]. Human pol $\delta$ and $\varepsilon$ were purified from the nuclear fraction of human 
peripheral blood cancer cells (Molt-4) using the second subunit of pol $\delta$ and $\varepsilon$-conjugated affinity column chromatography, respectively [25]. Pol I ( $\alpha$-like) and II ( $\beta$-like) from a higher plant, cauliflower inflorescence, were purified according to the methods outlined by Sakaguchi et al. [26]. The Klenow fragment of pol I from E. coli was purchased from Worthington Biochemical Corp. (Freehold, NJ, USA). Taq pol, T4 pol, T7 RNA polymerase and T4 polynucleotide kinase were obtained from Takara (Kyoto, Japan). Bovine pancreas deoxyribonuclease I was bought from Stratagene Cloning Systems (LaJolla, CA, USA).

\subsection{DNA polymerase assay}

Activities of pols were measured by methods described previously $[4,5]$. Poly(dA)/oligo(dT) $)_{12-18}$ and dTTP (2'-deoxythymidine 5'-triphosphate) were used as the template-primer DNA and nucleotide substrate, respectively. The activity without the inhibitor was considered $100 \%$, and the remaining activity at each concentration of inhibitor was determined relative to this value. One unit of pol activity was defined as the amount of enzyme that catalyzed the incorporation of $1 \mathrm{nmol}$ of deoxyribonucleotide triphosphates (i.e., dTTP) into synthetic template-primers (i.e. poly $(\mathrm{dA}) /$ oligo $\left.(\mathrm{dT})_{12-18}, \mathrm{~A} / \mathrm{T}=2 / 1\right)$ in $60 \mathrm{~min}$ at $37{ }^{\circ} \mathrm{C}$ under normal reaction conditions for each enzyme $[4,5]$.

\subsection{Effect of normal and conjugated PUFA on DNA polymerase}

Figure 1 shows the dose-response curves for each of the normal or conjugated EPA and DHA. Calf pol $\alpha$ and rat pol $\beta$ are representative replications and repair-related pols, respectively. Inhibition by these compounds was dose-dependent, with $50 \%$ inhibition of pol $\alpha$ by normal and conjugated PUFA, such as EPA and DHA, observed at 31.6 - 38.0 and $14.5-17.5 \mu \mathrm{M}$, respectively (Figure 1A), suggesting that conjugated PUFA was an approximately two-fold stronger pol $\alpha$ inhibitor than normal PUFA, and cEPA and cDHA consists of conjugated double bonds, and this structural feature may stimulate the inhibition of pol activity. Similarly, cEPA and cDHA inhibited pol $\beta$ activity, and the $\mathrm{IC}_{50}$ values were 32.1 and $46.8 \mu \mathrm{M}$, respectively (Figure 1B); therefore, the inhibition of conjugated PUFA for pol $\alpha$ was stronger than that for pol $\beta$. Furthermore, the inhibitory effect of cEPA was stronger than that of cDHA, and cEPA was the strongest inhibitor of all PUFA tested. Pols inhibition of cEPA was stronger than that of aphidicolin [27] or dideoxyTTP [28], well-known pols $\alpha$ and $\beta$ inhibitors, respectively.

In the kinetic analysis, the extent of inhibition as a function of DNA template-primer (i.e., poly(dA)/oligo(dT) $)_{12-18}$ ) or nucleotide substrate (i.e., dTTP) concentrations was studied. LineweaverBurk plots of the results show that the inhibition of pol $\alpha$ activity was non-competitive for both the DNA template-primer (the $\mathrm{K}_{\mathrm{m}}$ was unchanged at $13.0 \mu \mathrm{M}$ ) and the nucleotide substrate (the $\mathrm{K}_{\mathrm{m}}$ was unchanged at $1.65 \mu \mathrm{M})$. On the other hand, the inhibition of pol $\beta$ activity was competitive for both the DNA template-primer (the $\mathrm{V}_{\max }$ was unchanged at $111 \mathrm{pmol} / \mathrm{h}$ ) and the nucleotide substrate (the $\mathrm{V}_{\max }$ was unchanged at $62.5 \mathrm{pmol} / \mathrm{h}$ ) (data not shown). When activated DNA (i.e., DNA digested by bovine deoxyribonuclease I) and dNTP (i.e., dATP, dTTP, dGTP and dCTP) were used as the template-primer and nucleotide substrate, respectively, the mode of inhibition by these compounds did not change (data not shown). 
Figure 1. Dose-response curves of normal and conjugated PUFA for mammalian pol inhibition. (A) calf pol $\alpha$ and (B) rat pol $\beta$. Pol activity (0.05 units each) in the absence of the compounds was taken as $100 \%$. Values are shown as the means \pm SEM of three independent experiments.
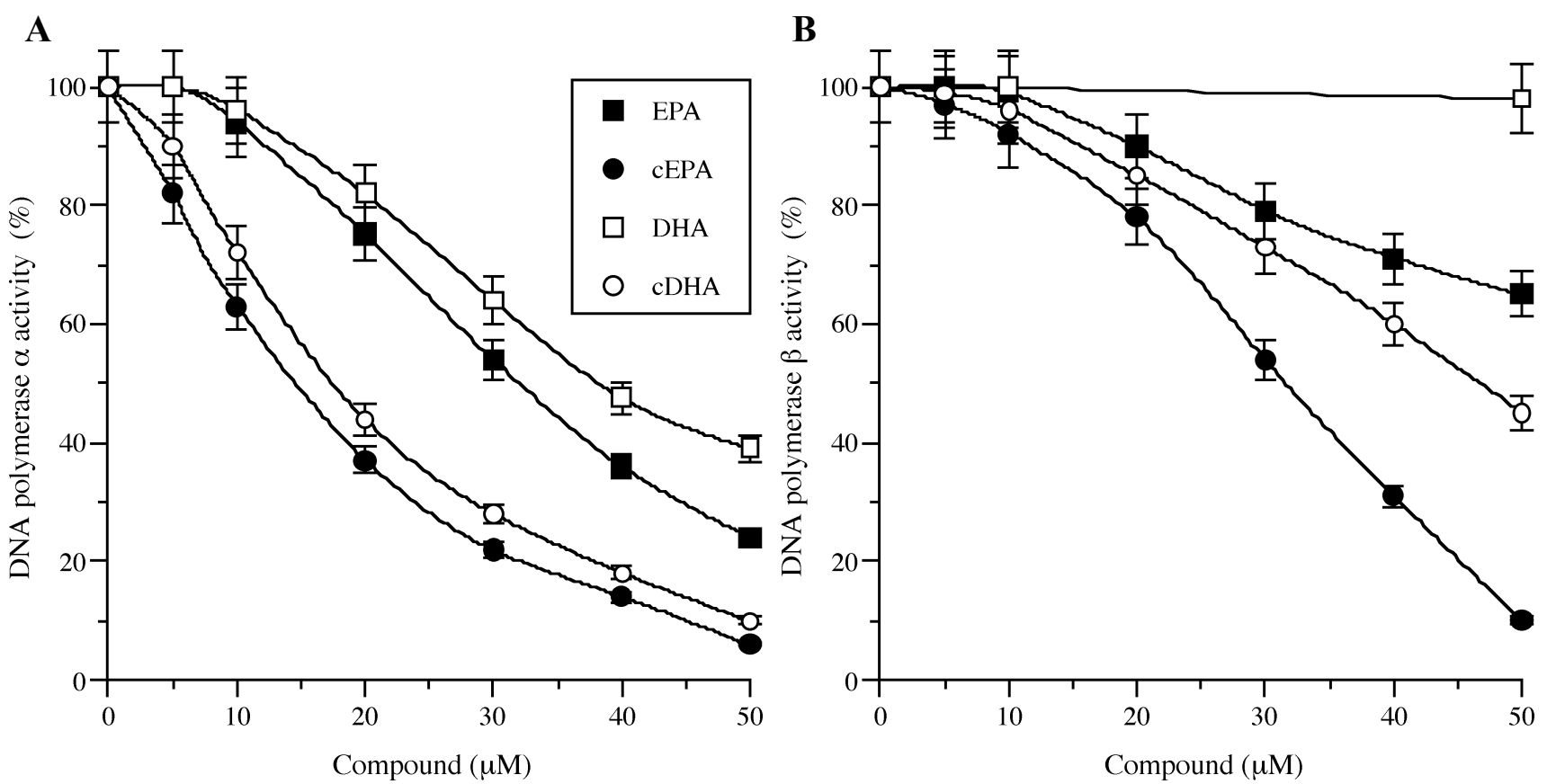

\section{DNA topoisomerase inhibition by normal and conjugated PUFA}

\subsection{DNA topoisomerase and DNA topoisomerase assay}

Topos are key enzymes that control the topological state of DNA. There are two classes of topos: type I enzymes which act by transiently nicking one of the two DNA strands and type II enzymes which nick both DNA strands are dependent on ATP, and are involved in many vital cellular processes that influence DNA replication, transcription, recombination, integration and chromosomal segregation [2]. Topo inhibitors are very rare, the most widely studied and characterized being camptothecin, a topo I poison [29], and etoposide and doxorubicin, topo II poisons [30]. In recent years, these enzymes have received special interest because topo inhibitors have emerged as anticancer [31] and anti-parasitic agents [32,33].

Human recombinant topo I and topo II $\alpha$ (topos I and II) (2 units $\mu$ l) were purchased from TopoGen, Inc. (Columbus, OH, USA). The catalytic activity (i.e., nicking activity) of topo I was determined by detecting the supercoiled plasmid DNA (i.e., supercoiled monomer, SM) in its nicked form (i.e., nicked monomer, NM). The topo I reaction was performed in $20 \mu \mathrm{l}$ of reaction mixture containing 10 $\mathrm{mM}$ Tris-HCl (pH 7.9), pBR322 DNA (250 ng), 1 mM EDTA, $150 \mathrm{mM} \mathrm{NaCl,} 0.1 \%$ bovine serum albumin (BSA), $0.1 \mathrm{mM}$ spermidine, $5 \%$ glycerol and 2 units of topo I. The catalytic activity of topo II was analyzed in the same manner except that the reaction mixture contained $50 \mathrm{mM}$ Tris- $\mathrm{HCl}(\mathrm{pH}$ 8.0), $120 \mathrm{mM} \mathrm{KCl}, 10 \mathrm{mM} \mathrm{MgCl} 2,0.5 \mathrm{mM}$ ATP, $0.5 \mathrm{mM}$ DTT, supercoiled pBR322 DNA (250 ng) and 2 units of topo II. The reaction mixtures were incubated at $37{ }^{\circ} \mathrm{C}$ for $30 \mathrm{~min}$, followed by $1 \%$ SDS and $1 \mathrm{mg} / \mathrm{ml}$ proteinase $\mathrm{K}$ digestion, and then $2 \mu \mathrm{l}$ of loading buffer was added consisting of $5 \%$ 
sarkosyl, $0.0025 \%$ bromophenol blue and $25 \%$ glycerol. The mixtures were subjected to $1 \%$ agarose gel electrophoresis in TBE buffer. The agarose gel was stained with ethidium bromide (EtBr) and the DNA was visualized under UV light.

\subsection{Effect of normal and conjugated PUFA on DNA topoisomerase}

As shown in Figure 2, the mobility of naturally supercoiled closed circular double-stranded plasmid DNA increases upon human topo I-mediated relaxation. Normal and conjugated PUFA, such as EPA and DHA, were able to inhibit topo I activity, and the inhibitory effect of cEPA was the strongest with an $\mathrm{IC}_{50}$ value of $0.5 \mu \mathrm{M}$. These compounds had the same inhibitory effect on human topo II as that on topo I (data not shown).

Figure 2. Inhibition of catalytic activity (i.e., nicking activity) of human topo I by normal and conjugated PUFA. (A) EPA and cEPA, (B) DHA and cDHA. Lane 1, supercoiled pBR322 DNA; lanes 2-10, DNA with 2 units of human topo I; lanes 3-6, inhibition of catalytic activity in the presence of $25,5,1$ or $0.2 \mu \mathrm{M}$ cEPA/cDHA; lanes 7-10, inhibition of catalytic activity in the presence of 25,5 , 1 or $0.2 \mu \mathrm{M}$ EPA/DHA. Positions of the supercoiled monomer (SM), nicked monomer (NM) and relaxed monomer $(\mathrm{RM})$ are indicated.

A

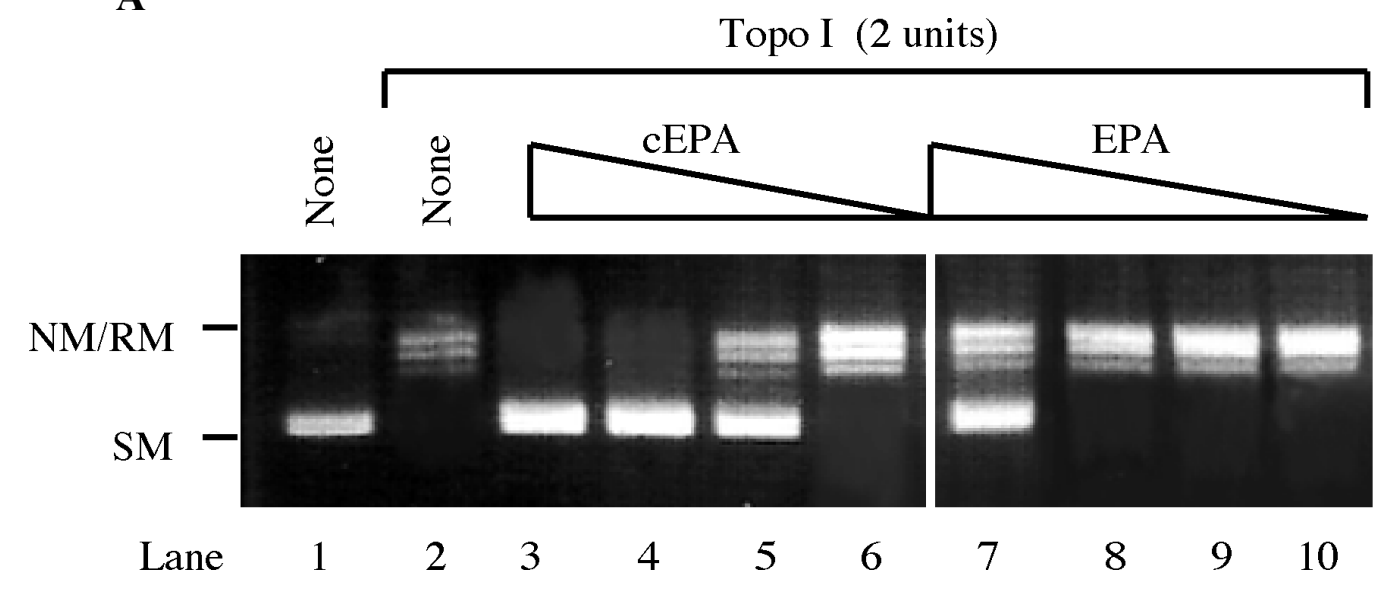

B

Topo I (2 units)

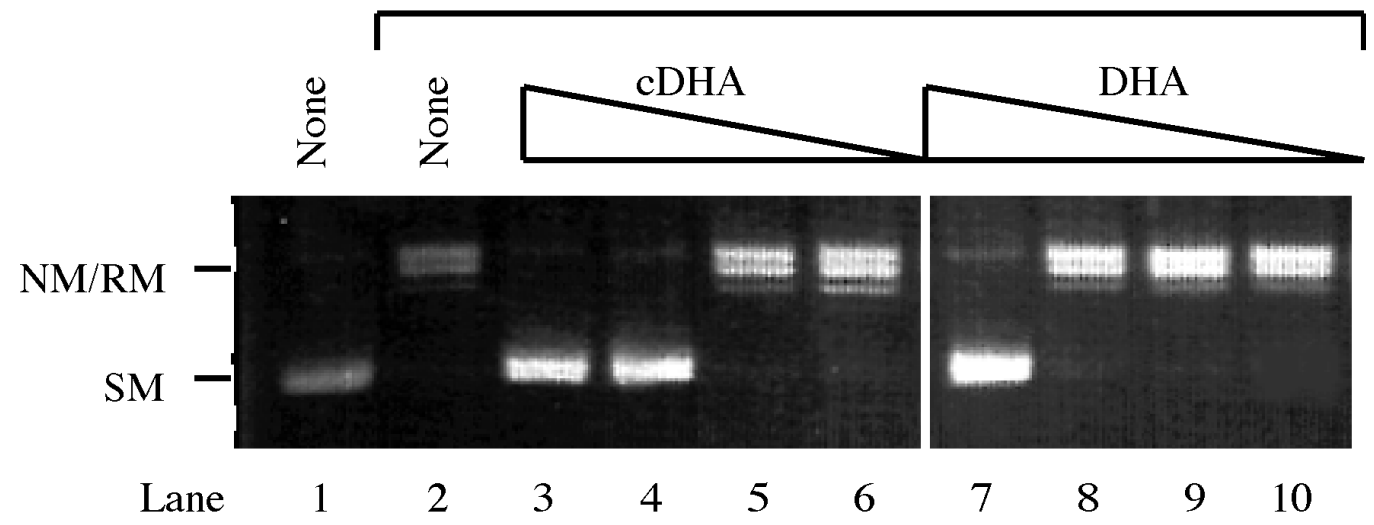




\section{Influence of cEPA and EPA on the hyperchromicity of double-stranded DNA}

To determine whether normal and conjugated PUFA binds to DNA, the melting temperature $\left(\mathrm{T}_{\mathrm{m}}\right)$ of dsDNA in the presence of $50 \mu \mathrm{M}$ of the compound was measured using a spectrophotometer equipped with a thermoelectric cell holder (Figure 3). Calf thymus dsDNA at $6 \mu \mathrm{g} / \mathrm{ml}$ was dissolved in $0.1 \mathrm{M}$ sodium phosphate buffer ( $\mathrm{pH} 7.0$ ) containing 1\% dimethylsulfoxide (DMSO). At this concentration of cEPA or EPA, no thermal transition of $\mathrm{T}_{\mathrm{m}}$ was observed, whereas $15 \mu \mathrm{M}$ of ethidium bromide (EtBr), a typical intercalating agent, caused a thermal transition. The compound at more than $100 \mu \mathrm{M}$ caused no thermal transition of $\mathrm{T}_{\mathrm{m}}$ (data not shown). Thus, none of the PUFA directly bound to the dsDNA, suggesting that they inhibit the activity by interacting with the enzymes, such as pols and topos, directly and inhibit their activities.

Figure 3. Effects of cEPA and EPA on the thermal transition of double-stranded DNA. Values are shown as the means \pm SEM of three independent experiments.

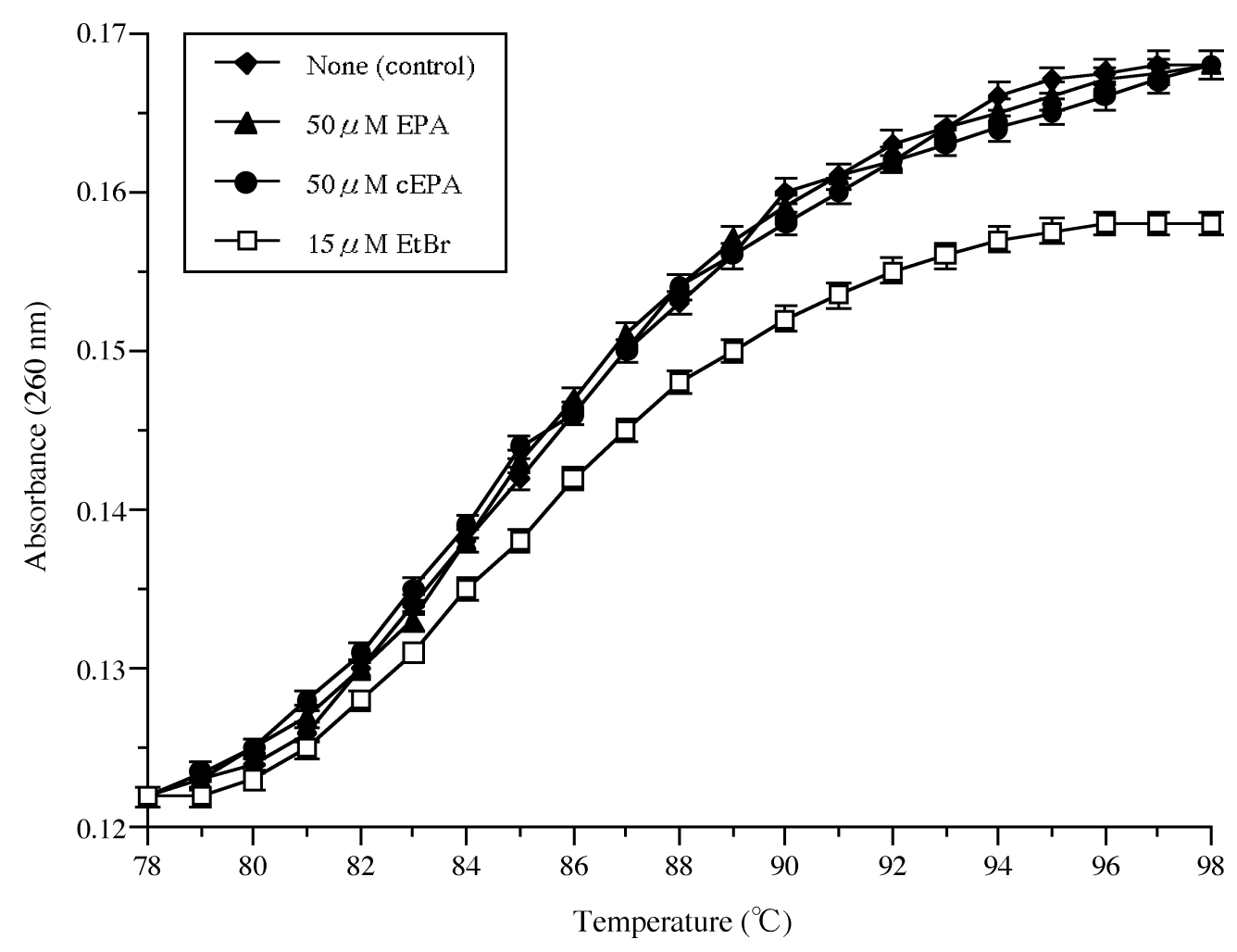

\section{Effects of EPA and cEPA on various pols and other DNA metabolic enzymes}

Table 1 shows $\mathrm{IC}_{50}$ values for various pols and DNA metabolic enzymes tested. Both normal PUFA, such as EPA, and conjugated PUFA, such as cEPA, significantly inhibited the activities of mammalian pols, such as replicative pols $\alpha, \delta$ and $\varepsilon$, repair-related pol $\beta$, and mitochondrial pol $\gamma$. Pol $\gamma$ inhibition by EPA/cEPA was strongest in the tested mammalian pols ( IC $_{50}$ values were 23.9 and 11.0 $\mu \mathrm{M}$, respectively), and the second inhibitory effect was pol $\alpha$; therefore, these compounds might suppress both mitochondrial and nuclear DNA replications.

EPA and cEPA had little inhibitory effect on the activities of higher plant (cauliflower) pols I ( $\alpha$ like pol) and II ( $\beta$-like pol), prokaryotic pols, such as the Klenow fragment of E. coli pol I, Taq pol and 
T4 pol, and DNA metabolic enzymes, such as calf RNA primase of pol $\alpha$, T7 RNA polymerase, T4 polynucleotide kinase and bovine deoxyribonuclease I (Table 1). On the other hand, these compounds strongly inhibited the catalytic activities of human topos I and II. cEPA was the strongest topos I and II inhibitor of the compounds tested with $\mathrm{IC}_{50}$ values of 0.5 and $2.5 \mu \mathrm{M}$, respectively (Table 1). The $\mathrm{IC}_{50}$ of cEPA for topo I was the smallest value obtained for any of the DNA metabolic enzymes tested, and the inhibition of topo I and topo II by cEPA was approximately 20 -fold and 4-fold stronger than that of pols, respectively. These results suggested that cEPA might be a potent inhibitor of pols and topos, which could be molecular targets for anticancer chemotherapy. We therefore reviewed the mechanism of the inhibitory effect of cEPA on human cancer cells.

Table 1. $\mathrm{IC}_{50}$ values of EPA and cEPA for the activities of various DNA polymerases and other DNA metabolic enzymes.

\begin{tabular}{|c|c|c|}
\hline \multirow{2}{*}{ Enzyme } & IC 50 value & $(\mu \mathbf{M})$ \\
\hline & EPA & cEPA \\
\hline \multicolumn{3}{|l|}{--- Mammalian DNA polymerases --- } \\
\hline Calf DNA polymerase $\alpha$ & $32.1 \pm 1.9$ & $14.5 \pm 0.9$ \\
\hline Rat DNA polymerase $\beta$ & $88.5 \pm 5.3$ & $31.6 \pm 1.9$ \\
\hline Human DNA polymerase $\gamma$ & $23.9 \pm 1.4$ & $11.0 \pm 0.7$ \\
\hline Human DNA polymerase $\delta$ & $39.2 \pm 2.4$ & $31.8 \pm 2.0$ \\
\hline Human DNA polymerase $\varepsilon$ & $35.0 \pm 2.1$ & $27.4 \pm 1.6$ \\
\hline \multicolumn{3}{|l|}{--- Plant DNA polymerases --- } \\
\hline Cauliflower DNA polymerase I ( $\alpha$ like) & $>100$ & $>100$ \\
\hline Cauliflower DNA polymerase II ( $\beta$ like) & $>100$ & $>100$ \\
\hline \multicolumn{3}{|l|}{--- Prokaryotic DNA polymerases --- } \\
\hline E. coli DNA polymerase I (Klenow fragment) & $>100$ & $>100$ \\
\hline Taq DNA polymerase & $>100$ & $>100$ \\
\hline T4 DNA polymerase & $>100$ & $>100$ \\
\hline \multicolumn{3}{|l|}{--- Other DNA metabolic enzymes --- } \\
\hline Calf RNA primase of DNA polymerase $\alpha$ & $>100$ & $>100$ \\
\hline T7 RNA polymerase & $>100$ & $>100$ \\
\hline T4 polynucleotide kinase & $>100$ & $>100$ \\
\hline Bovine deoxyribonuclease I & $>100$ & $>100$ \\
\hline Human DNA topoisomerase I & $20.0 \pm 2.0$ & $0.5 \pm 0.1$ \\
\hline Human DNA topoisomerase II & $10.0 \pm 1.0$ & $2.5 \pm 0.3$ \\
\hline
\end{tabular}

Enzyme activity in the absence of the compound was taken as $100 \%$. Pol activities were 0.05 units each. Values are shown as the means \pm SEM of three independent experiments. 


\section{Effects of cEPA on inhibition of human cancer cell growth}

To determine the effects of cEPA on cultured human cancer cells, we tested their influence on cell growth in two leukemia cell lines, NALM-6 and HL-60. NALM-6 is a normal cell line which has a p53 gene, and HL-60 is a mutant cell line which has a p53 gene deletion. As shown in Figure 4, cEPA efficiently inhibited cell growth of both NALM-6 and HL-60 in a dose-dependent manner. After 24 hours of treatment, the LD $_{50}$ values of cEPA on NALM-6 and HL-60 cells were 37.5 and $12.5 \mu \mathrm{M}$, respectively. Since the cell growth effect of cEPA on the HL-60 cell line was more cytotoxic than that on the NALM-6 cell line, p53 protein expression must related to cell growth inhibition by cEPA, which is a selective inhibitor of pols and topos. The inhibitory concentrations of cell growth were almost the same as the inhibitory effect of mammalian pols rather than topos. We investigated in more detail which inhibition by cEPA is effective for cancer cell proliferation, that of pols or topos.

Figure 4. Effect of cEPA on the proliferation of a human cancer cell line.

Cell proliferation was determined by MTT assay [34]. Values are shown as the means \pm SEM of four independent experiments.

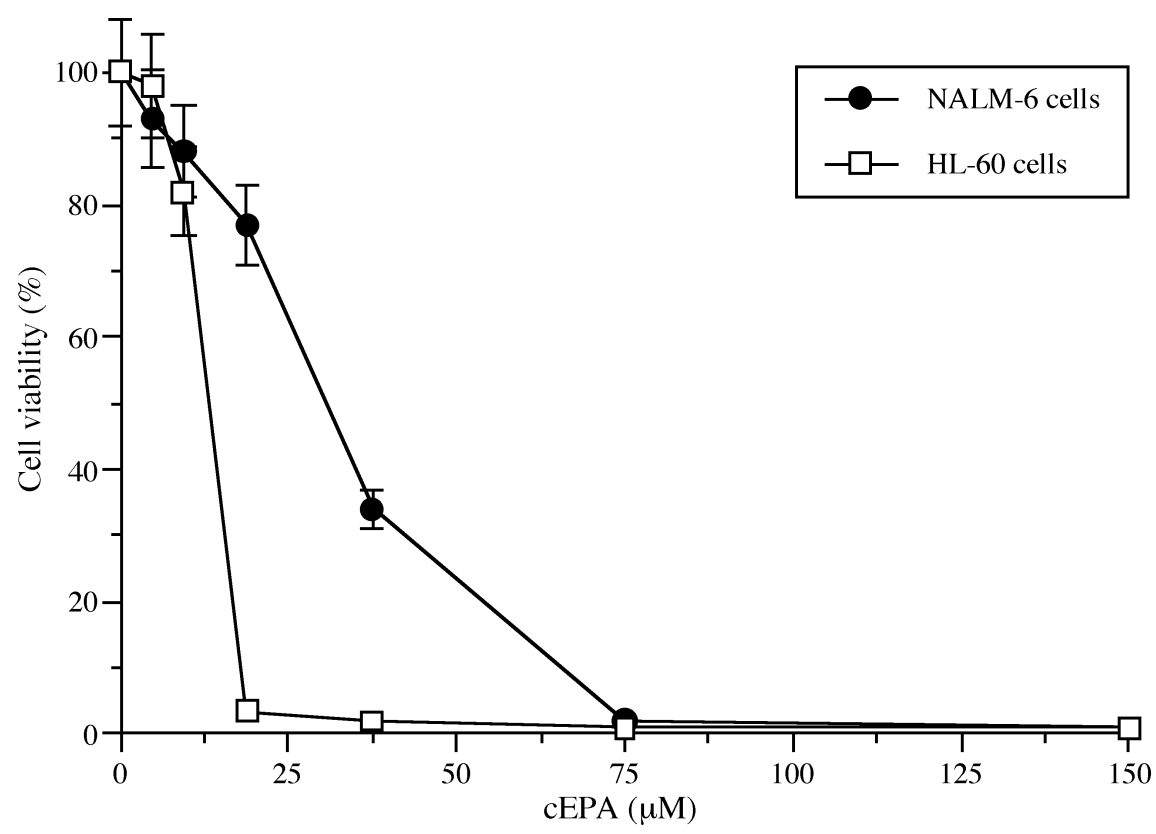

\section{Effects on the cell cycle progression of cEPA}

Next, we analyzed whether cEPA affected the cell cycle distribution of cEPA-treated cells. The cell cycle fraction was recorded after 24 hours of treatment with the $\mathrm{LD}_{50}$ value of cEPA, and was compared with cells incubated in medium alone. The ratio of the three phases (i.e., G1, S and G2/M) in the cell cycle is shown in Figure 5. Consequently, among NALM-6 cells, which have the p53 gene, treated with $37.5 \mu \mathrm{M}$ cEPA, the population of cells in the G1 phase increased significantly (32.9 \% to $47.6 \%$ ), and the percentage of cells in the $\mathrm{S}$ phase decreased from $53.8 \%$ to $37.1 \%$. Similarly, HL60 cells, which does not have the p53 gene, clearly increased the G1 phase (32.9\% to $46.5 \%)$, and decreased the $\mathrm{S}$ and $\mathrm{G} 2 / \mathrm{M}$ phases (53.8 \% to $44.6 \%$ and $13.3 \%$ to $8.9 \%$, respectively) treated with $12.5 \mu \mathrm{M}$ cEPA. These results suggested that the actions of cEPA block from G1 to an early stage of 
the S phase in both NALM-6 and HL-60 cells, and p53 protein in the cells might not be effective for cell cycle regulation. Dehydroaltenusin, which is a specific pol $\alpha$ inhibitor, inhibited the cell cycle in the S phase [35], and classical topo inhibitors, such as etoposide, arrested the cell cycle in the G2 phase [36]. cEPA, therefore, might be more effective in the inhibition of pols than topos in the cell, although cEPA inhibited the activities of mammalian pols and human topos, and the inhibitory effect for topos was stronger than that for pols in vitro (Table 1).

Figure 5. The effect of cEPA on the cell cycle. Flow cytometric analysis of NALM-6 cells and HL-60 cells were incubated without (control) or with the $\mathrm{LD}_{50}$ values of cEPA (i.e., 37.5 and $12.5 \mu \mathrm{M}$, respectively) for 24 hours. Cell cycle distribution was calculated as the percentage of cells in the G0/G1, S and G2/M phase. All experiments were performed three times.

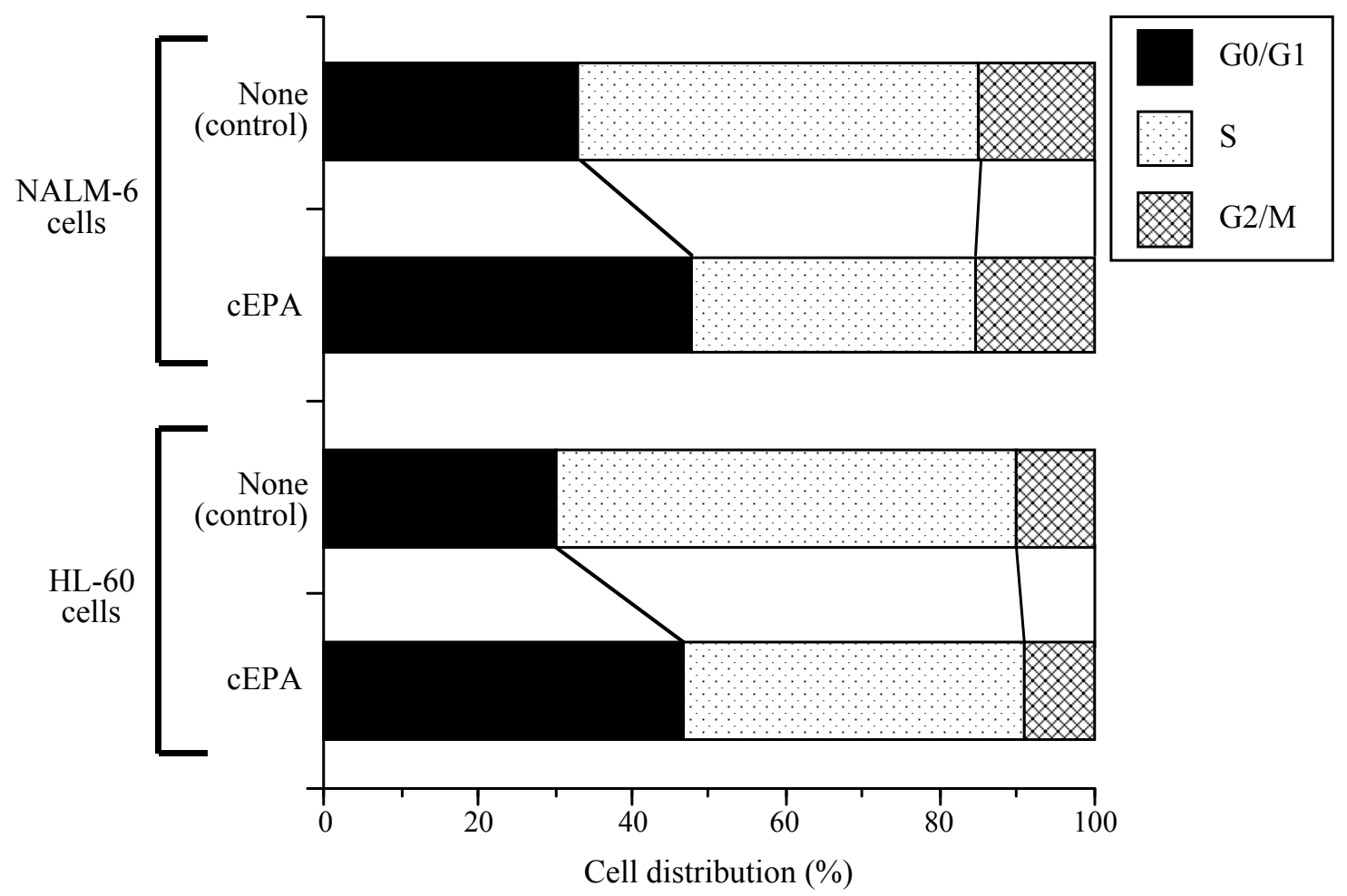

We examined whether the cell cycle effect of cEPA was associated with the expression of cyclin proteins using Western blotting. Cyclin E protein is present from the end of the G1 to early S phase, and cyclin A protein keeps accumulating from the G1 to $S$ phase [37, 38]. It was suggested that cyclins $\mathrm{A}$ and $\mathrm{E}$ link the transition mechanism from the G1 to S phase, and appear when the cells start to synthesize DNA $[37,38]$. On the other hand, cyclin B was associated with the mechanism of G2/M transition [38]. As shown in Table 2, the expression of cyclin A proteins did not change and slightly decreased with the $\mathrm{LD}_{50}$ value of cEPA treatment in NALM-6 cells and HL-60 cells, respectively. On the other hand, cyclin E proteins strongly increased, but cyclin B decreased in both cell lines. These results suggested that cEPA induced and reduced the protein expression of cyclin $\mathrm{E}$ and cyclin $\mathrm{B}$, respectively, in human cancer cells with or without $\mathrm{p} 53$, and then the cyclins arrested human cancer cells in the G1/S phase. The inhibition of pols and topos activities by cEPA might lead to the translation of cyclin proteins. 
Table 2. Protein expressions of the extract of human cancer cells by cEPA influences using Western blotting.

\begin{tabular}{|c|c|c|}
\hline Protein & NALM-6 cells & HL-60 cells \\
\hline \multicolumn{3}{|l|}{-- Cyclin -- } \\
\hline Cyclin A & $\rightarrow$ & $\downarrow$ \\
\hline Cyclin B & $\downarrow$ & $\downarrow$ \\
\hline Cyclin E & $\uparrow \uparrow$ & $\uparrow \uparrow$ \\
\hline \multicolumn{3}{|c|}{-- p53-upstream signaling pathway -- } \\
\hline RPA70 & $\uparrow$ & $\uparrow$ \\
\hline ATR & $\uparrow$ & $\uparrow$ \\
\hline Chk1 & $\rightarrow$ & $\rightarrow$ \\
\hline Chek1-P ${ }^{(\mathrm{A})}$ & $\uparrow \uparrow$ & $\uparrow \uparrow$ \\
\hline Chk2 & $\rightarrow$ & $\rightarrow$ \\
\hline Chek2-P ${ }^{(\mathrm{B})}$ & $\uparrow \uparrow$ & $\uparrow \uparrow$ \\
\hline \multicolumn{3}{|c|}{-- p53-downstream signaling pathway -- } \\
\hline p53 & $\rightarrow$ & ND \\
\hline p53-P (C) & $\uparrow$ & ND \\
\hline p21 & $\uparrow$ & $\downarrow$ \\
\hline $\mathrm{Cdc} 25 \mathrm{~A}$ & $\downarrow$ & $\downarrow$ \\
\hline \multicolumn{3}{|c|}{ 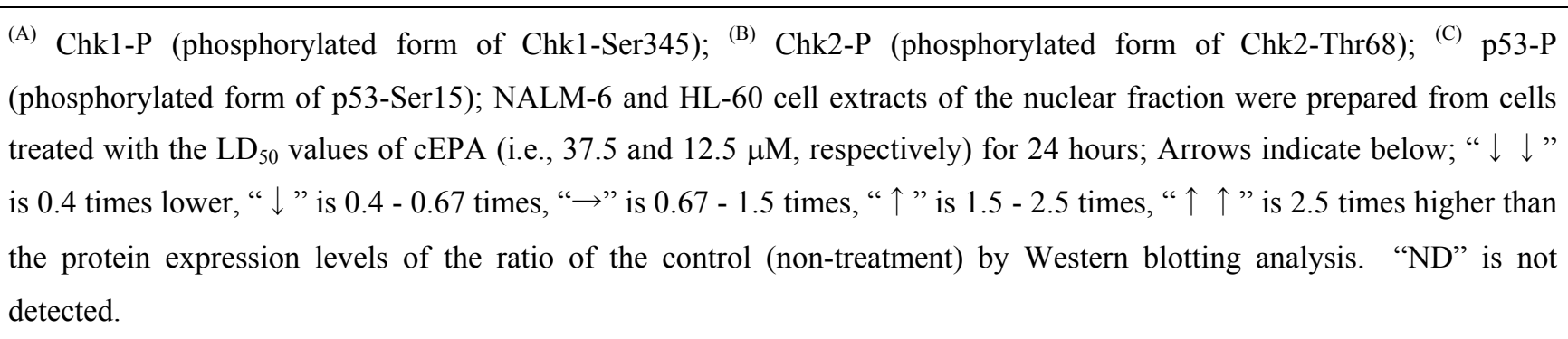 } \\
\hline
\end{tabular}

\section{Effect on protein expression of checkpoint proteins by cEPA.}

To study the mechanism of cEPA-induced cell cycle block further in comparison with or without the p53 gene, the protein expressions of p53-upstream and p53-downstream signaling pathways were investigated by Western blotting. The expression level of the related proteins for DNA damage checkpoint (i.e., p53-upstream signaling pathways) with the $\mathrm{LD}_{50}$ value of cEPA treatment in NALM6 cells was shown in Table 2. A recent report demonstrated that the uncoupling of helicase and pol activities, which leads to the formation of long regions of RPA (replication protein A)-coated singlestranded DNA (ssDNA) at replication forks, is necessary for ATR (ataxia-telangiectasia mutated- and Rad3-related protein kinase) checkpoint signaling in Xenopus extracts [39]. RPA70 (70 kDa subunit of RPA) and ATR were time-dependently increased by cEPA treatment. Although the expression levels of Chk1 and Chk2, which regulate the DNA replication checkpoint, had no influence, these proteins were clearly phosphorylated. These protein expressions on the cancer cell line HL-60 of p53null mutant had the same tendency as those on NALM-6 cells of p53-wild type (Table 2). 
Cell cycle control is the major regulatory mechanism of cell growth [40]. The cell cycle is regulated by the coordinated action of cyclin-dependent kinases (cdks) in association with their specific regulatory cyclin proteins. Cdk inhibitors, including $\mathrm{p} 21$, also contribute to the regulation of cell cycle progression by controlling cdk activity. p21 inhibits a wide variety of cyclin-cdk complexes in vitro, including cdk4 and cdk2 complexes which are activated early in the G1 phase [41, 42], and overexpression of these proteins blocks the progression of cells through G1 [43]. p53 plays the central role in the G1 phase arrest because it is known to be an upstream regulator of p21, a cdk inhibitor. To explore the mechanisms of cEPA-induced cell cycle arrest, the expression of p53 protein and cdk inhibitor, p21 protein, was examined by Western blotting because these inhibitory proteins play a negative regulatory role in the G1 phase, and disappearance of these inhibitory activities is associated with G1/S progression induced by a number of mitogens $[44,45]$. When NALM-6 cells were incubated with $37.5 \mu \mathrm{M}$ cEPA, the p53 protein expression did not change, but the expression of phosphorylated-p53 markedly increased time-dependently (Table 2). The p21 protein expression also increased in parallel to the phosphorylated-p53 protein expression. Since cEPA-induced cell cycle arrest showed time dependence, these results suggested that p53 and p21 proteins might be held in a state of active repression in cells that have stalled DNA replication forks, and were expressed with cell cycle arrest. On the other hand, HL-60, which is a p53-null mutant, could not detect the protein expression of not only p53 and phosphorylated-p53, but also p21, suggesting that p21 protein was not expressed because of the absence of phosphorylated-p53 protein.

The current concept of a cell cycle checkpoint response places the regulatory kinase Chk1/2 upstream from Cdc25A [46]. Cdc25A is involved in the G1 to intra-S phase checkpoint, and the level reaches a maximum in the end of the G1 phase and the early S phase [47]. Both NALM-6 and HL-60 cells had blocked Cdc25A protein expression by cEPA treatment. Cdc25A dephosphorylates and activates the cyclin E-cdk2 complex that is activate during G1 phase [48], and it is reported that reduction of reduction of $\mathrm{Cdc} 25 \mathrm{~A}$ contributes to cyclin E-cdk2 inhibition and $\mathrm{G} 1$ arrest [49]. Therefore, G1 transition arrest by cEPA showed a relationship to Cdc25A protein suppression.

\section{Effects of cEPA on apoptosis}

To examine whether the decrease in cell numbers caused by cEPA was due to apoptosis, DNA fragmentation was analyzed by electrophoresis. DNA ladder formation was detected at 6 hours and time-dependently increased in both NALM-6 and HL-60 cells treated with the LD $_{50}$ value of cEPA (Figure 6). In cell cycle analysis, cEPA-treated cells were in the sub-G1 phase (data not shown). These results suggested that the effect of cEPA must involve a combination of growth arrest and cell death, and apoptosis by cEPA led to both a p53-dependent pathway and p53-independent pathway (e.g., cell death receptor, reactive oxygen species (ROS), and so on). 
Figure 6. Effect of cEPA on the induction of apoptosis. The total DNA was extracted from NALM-6 cells and HL-60 cells after exposure to the $\mathrm{LD}_{50}$ values of cEPA (i.e., 37.5 and $12.5 \mu \mathrm{M}$, respectively) for the indicated times, and then each DNA extract was applied to the gel. Nucleosomal DNA fragmentation was analyzed by agarose gel electrophoresis.

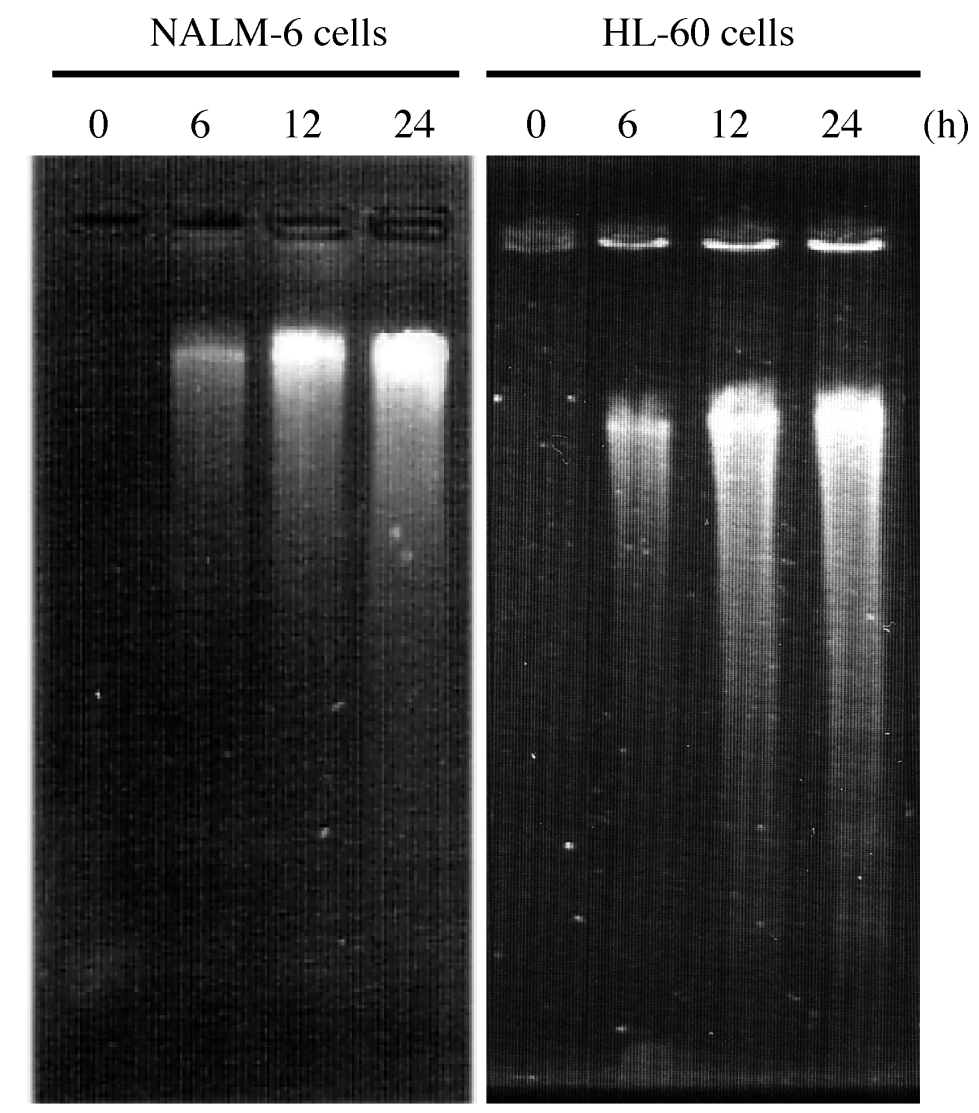

\section{Discussion}

In this review, the mechanisms by which cEPA suppresses cancer cell growth were investigated, and it was revealed that the inhibition of mammalian pols and human topos activities by cEPA influenced not only cell proliferation but also cell cycle arrest in the G1 phase. It is considered that the inhibition of pols and topos activities could be 'DNA replication stress' (Figure 7). Upon perturbation of DNA synthesis by inhibitors of DNA replication such as cEPA, the rate of DNA unwinding becomes greater than the rate of DNA synthesis, leading to functional uncoupling of topos from replicative pols. As shown in Figure 7, it is suggested that this results in the creation of large regions of unwound ssDNA and leads to the accumulation of RPA, ATRIP (ATR-interacting protein) and ATR on chromation [50]. As unwinding occurs, the pol $\alpha$-primase complex begins DNA synthesis on the unwound DNA. The induced proximity of ATR at primer/template junctions then must lead to Chk1/2 phosphorylation [51].

Cell cycle arrest in the G1 phase by cEPA, which is a selective inhibitor of mammalian pols and topos, is considered to be induced to the $\mathrm{p} 53 / \mathrm{p} 21$ pathway from the ATR-Chk1/2 signaling pathway in p53-wild cells such as NALM-6 (Figure 7A). On the other hand, ectopic expression of Chk1/2 from 
the p53-upstream signaling pathway could prevent the phosphorylate Cdc25A, and then store the G1 phase arrest in p53-null cells such as HL-60 (Figure 7B).

Figure 7. Role of p53 in the prevention of cell cycle arrest and cell death by cEPA. (A) DNA replication fork inhibitors such as cEPA activate p53 that triggers p21 activation and prevents the cell cycle from G1 to S phase development. (B) The lack of p53 leads to cell cycle arrest in the G1 phase by $\mathrm{Cdc} 25 \mathrm{~A}$ and results in apoptosis of virtually the entire cell population.

(A) p53-wild type (NALM-6 cells)

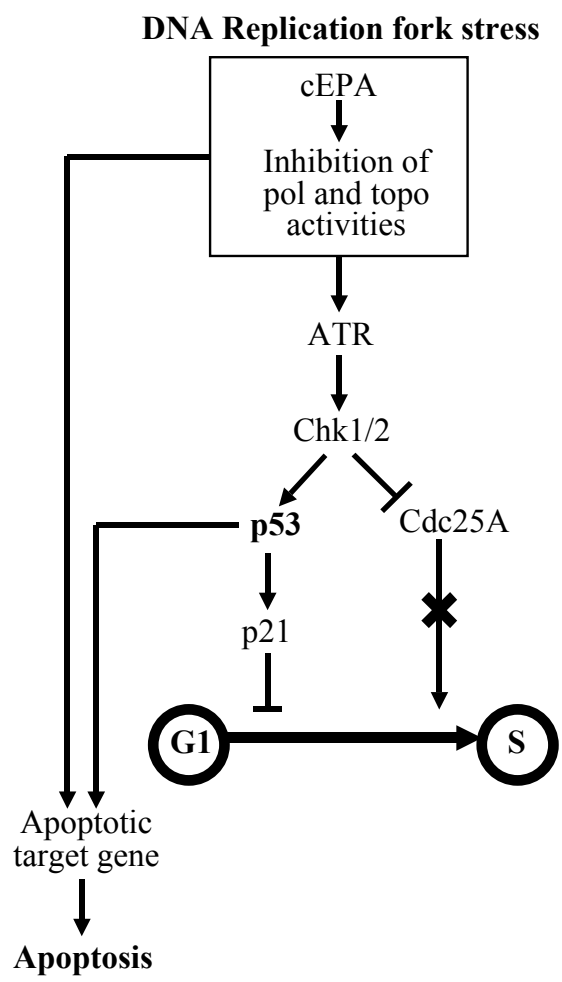

(B) p53-null (HL-60 cells)

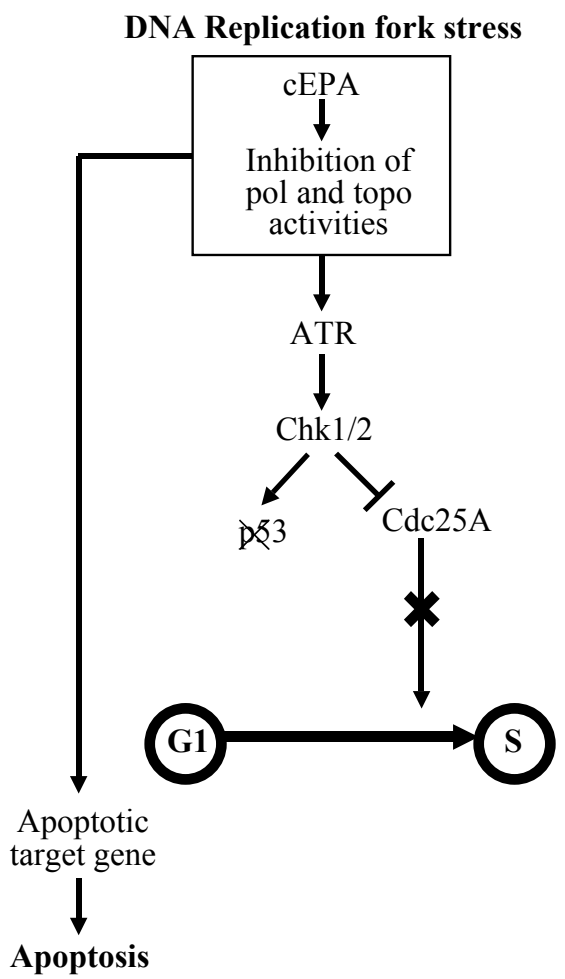

\section{Conclusion}

In this review, we described whether PUFA and conjugated PUFA prepared by alkaline treatment of PUFA inhibited the activities of mammalian pols and human topos, and found that the inhibitory effect of cEPA on the activities of topos I and II is stronger than that on pols activities (Figures 1 and 2) [52]. cEPA did not influence pols activities from plants and prokaryotes and other DNA metabolic enzymes activities (Table 1), and no interaction of cEPA with DNA was detected in an independent DNA-binding assay (i.e., $\mathrm{T}_{\mathrm{m}}$ of dsDNA measurements of Figure 3). These results suggested that selective inhibitory action by PUFA might be due to specific binding to pol and topo enzymes. We investigated whether an excessive amount of poly $(\mathrm{rC})(200 \mu \mathrm{g} / \mathrm{ml})$ or bovine serum albumin (BSA) $(200 \mu \mathrm{g} / \mathrm{ml})$ could prevent the inhibitory effect of PUFA to determine whether the effect of PUFA resulted from the non-specific adhesion of PUFA to the enzymes of mammalian pols and human topos, or bound selectively to special sites. Poly $(\mathrm{rC})$ and BSA had little or no influence on the inhibitory effect of PUFA, suggesting that binding to mammalian pols and human topos occurs selectively (data not shown). 
Furthermore, the mechanisms by which cEPA suppresses cancer cell growth were investigated, and it was revealed that the inhibition of pol activity by cEPA, which is an inhibitor of mammalian pols and topos, influenced not only cell proliferation but also the cell cycle (Figures 4 and 5) [53, 54]. The compound induced cell apoptosis (Figure 6) through both p53-dependent and p53-independent pathways (Table 2 and Figure 7) [54].

Inhibitors of pols could also be anti-cancer agents, as reported previously $[55,56]$, and pols and topos have recently emerged as important cellular targets for chemical intervention in the development of anti-cancer agents. The chemical structure of PUFA containing conjugated double bonds could, moreover, be used for screening new anti-cancer agents, because the conjugated form of EPA (i.e., cEPA) was a two-fold stronger pol inhibitor than normal EPA. Since cEPA did not influence the proliferation of normal cells (data not shown), cEPA should also be considered the lead compound of a group of potentially useful agents for cancer chemotherapy.

\section{Acknowledgements}

We are grateful for the donations of calf pol $\alpha$, rat pol $\beta$, human pol $\gamma$, and human pols $\delta$, $\varepsilon$ by Dr. M. Takemura of Tokyo University of Science (Tokyo, Japan), Dr. A. Matsukage of Japan Women's University (Tokyo, Japan), Dr. M. Suzuki of Nagoya University (Nagoya, Japan), and Dr. K. Sakaguchi of Tokyo University of Science (Chiba, Japan), respectively.

This work was supported in part by a Grant-in-aid for Kobe-Gakuin University Joint Research (A), and "Academic Frontier" Project for Private Universities: matching fund subsidy from the Ministry of Education, Science, Sports, and Culture of Japan (MEXT), 2006-2010, (Y. M. and H. Y.). Y. M. acknowledges a Grant-in-Aid for Young Scientists (A) (No. 19680031) from MEXT, and a Grant-inaid from the Nakashima Foundation (Japan).

\section{References and Notes}

1. Kornberg, A.; Baker, T.A. DNA replication, $2^{\text {nd }}$ Ed.; W.D. Freeman and Co.: New York, 1992; Chapter 6, pp. 197-225.

2. Wang, J.C. DNA topoisomerases. Annu. Rev. Biochem. 1996, 65, 635-691.

3. Mizushina, Y.; Yagi, H.; Tanaka, N.; Kurosawa, T.; Seto, H.; Katsumi, K.; Onoue, M.; Ishida, H.; Iseki, A.; Nara, T.; Morohashi, K.; Horie, T.; Onomura, Y.; Narusawa, M.; Aoyagi, N.; Takami, K.; Yamaoka, M.; Inoue, Y.; Matsukage, A.; Yoshida, S.; Sakaguchi, K. Screening of inhibitor of eukaryotic DNA polymerases produced by microorganisms. J. Antibiot. (Tokyo) 1996, 49, 491492.

4. Mizushina, Y.; Tanaka, N.; Yagi, H.; Kurosawa, T.; Onoue, M.; Seto, H.; Horie, T.; Aoyagi, N.; Yamaoka, M.; Matsukage, A.; Yoshida, S.; Sakaguchi, K. Fatty acids selectively inhibit eukaryotic DNA polymerase activities in vitro. Biochim. Biophys. Acta 1996, 1308, 256-262.

5. Mizushina, Y.; Yoshida, S.; Matsukage, A.; Sakaguchi, K. The inhibitory action of fatty acids on DNA polymerase $\beta$. Biochim. Biophys. Acta 1997, 1336, 509-521.

6. Mizushina, Y.; Sugawara, F.; Iida, A.; Sakaguchi, K. Structural homology between DNA binding sites of DNA polymerase $\beta$ and DNA topoisomerase II. J. Mol. Biol. 2000, 304, 385-395. 
7. Fernandez, E.; Chatenoud, L.; La Vecchia, C.; Negri, E.; Franceschi, S. Fish consumption and cancer risk. Am. J. Clin. Nutr. 1999, 70, 85-90.

8. Lindner, M.A. A fish oil diet inhibits colon cancer in mice. Nutr. Cancer 1991, 15, 1-11.

9. Reddy, B.S.; Burill, C.; Rigotty, J. Effect of diets high in omega-3 and omega-6 fatty acids on initiation and postinitiation stages of colon carcinobenesis. Cancer Res. 1991, 51, 487-491.

10. Hirose, M.; Masuda, A.; Ito, N.; Kamano, K.; Okuyama, H. Effects of dietary perilla oil, soybean oil and safflower oil on 7,12-dimethylbenz $(\alpha)$ anthracene (DMBA) and 1,2-dimethylhydrazine (DMH)-induced mammary gland and colon carcinogenesi in female SD rats. Carcinogenesis 1990, $11,731-735$.

11. Iigo, M.; Nakagawa, T.; Iwahori, Y.; Asamoto, M.; Yazawa, K.; Araki, E.; Tsuda, H. Inhibitory effects of docosahexaenoic acid on colon carcinoma 26 metastasis to the lung. Br. J. Cancer 1997, $75,650-655$.

12. Iwamoto, S.; Senzaki, H.; Kiyozuka, Y.; Ogura, E.; Takada, H.; Hioki, K.; Tsubura, A. Effects of fatty acids on liver metastasis of ACL15 rat colon cancer cells. Nutr. Cancer 1998, 31, 143-150.

13. Ha, Y.L.; Grimm, N.K.; Pariza, M.W. Anticarcinogens from fried ground beef: heat-altered derivatives of linoleic acid. Carcinogenesis 1987, 8, 1881-1887.

14. Park, H.S.; Ryu, J.H.; Ha, Y.L.; Park, J.H. Dietary conjugated linoleic acid (CLA) induces apoptosis of colonic mucosa in 1,2-dimethylhydrazine-treated rats: a possible mechanism of the anticarcinogenic effect by CLA. Br. J. Nutr. 2001, 86, 549-555.

15. Shultz, T.D.; Chew, B.P.; Seaman, W.R.; Luedecke, L. O. Inhibitory effect of conjugated dienoic derivatives of linoleic acid and $\beta$-carotene on the in vitro growth of human cancer cells. Cancer Lett. 1992, 63, 125-133.

16. Kelly, G.S. Conjugated linoleic acid: a review. Alern. Med. Rev. 2001, 6, 367-382.

17. Lopez, A.; Gerwick, W.H. Two new icosapentaenoic acids from the temperate red seaweed Ptilota filicina. J. Agardh. Lipids 1987, 22, 190-194.

18. Mikhailova, M.V.; Bemis, D.L.; Wise, M.L.; Gerwick, W.H.; Norris, J.N.; Jacobs, R.S. Structure and biosynthesis of novel conjugated polyene fatty acids from the marine green alga Anadyomene stellata. Lipids 1995, 30, 583-589.

19. Association of Official Analytical Chemists. Acids (poly-unsaturated) in oil and fats. In Official Methods of Analysis of the Association of Official Analytical Chemists; Helrich, K., Ed.; Association of Official Analytical Chemists: Arlington, 1990; pp. 960-963.

20. Pitt, G.A.J.; Morton, R.A. Prog. Chem. Fats Other Lipids 1957, 4, $227-278$.

21. Friedberg, E.C.; Feaver, W.J.; Gerlach, V.L. The many faces of DNA polymerases: strategies for mutagenesis and for mutational avoidance. Proc. Natl. Acad. Sci. U.S.A. 2000, 97, 5681-5683.

22. Tamai, K.; Kojima, K.; Hanaichi, T.; Masaki, S.; Suzuki. M.; Umekawa, H.; Yoshida, S. Structural study of immunoaffinity-purified DNA polymerase $\alpha$-DNA primase complex from calf thymus. Biochim. Biophys. Acta 1988, 950, 263-273.

23. Date, T.; Yamaguchi, M.; Hirose, F.; Nishimoto, Y.; Tanihara, K.; Matsukage, A. Expression of active rat DNA polymerase $\beta$ in Escherichia coli. Biochemistry 1988, 27, 2983-2990. 
24. Yonezawa, Y.; Kuriyama, I.; Fukuoh, A.; Muta, T.; Kang, D.; Takemura, M.; Kato, I.; Yoshida, H.; Mizushina, Y. Inhibitory effect of coenzyme Q on eukaryotic DNA polymerase $\gamma$ and DNA topoisomerase II activities on the growth of a human cancer cell line. Cancer Sci. 2006, 97, 716723.

25. Oshige, M.; Takeuchi, R.; Ruike, R.; Kuroda, K.; Sakaguchi, K. Subunit protein-affinity isolation of Drosophila DNA polymerase catalytic subunit. Protein Expr. Purif. 2004, 35, 248-256.

26. Sakaguchi, K.; Hotta, Y.; Stern, H. Chromatin-associated DNA polymerase activity in meiotic cells of lily and mouse. Cell Struct. Funct. 1980, 5, 323-334.

27. Ikegami, S.; Taguchi, T.; Ohashi, M.; Oguro, M.; Nagano, H.; Mano, Y. Aphidicolin prevents mitotic cell division by interfering with the activity of DNA polymerase- $\alpha$. Nature 1978, 275, 458-460.

28. Izuta, S.; Saneyoshi, M.; Sakurai, T.; Suzuki, M.; Kojima, K.; Yoshida, S. The 5'-triphosphates of 3'-azido-3'-deoxythymidine and 2', 3'-dideoxynucleosides inhibit DNA polymerase $\gamma$ by different mechanisms. Biochem. Biophys. Res. Commun. 1991, 179, 776-783.

29. Hsiang, Y.H.; Hertzberg, R.; Hecht, S.; Liu, L.F. Camptothecin induces protein-linked DNA breaks via mammalian DNA topoisomerase I. J. Biol. Chem. 1985, 260, 14873-14878.

30. Burden, D.A.; Osheroff, N. Mechanism of action of eukaryotic topoisomerase II and drugs targeted to the enzyme. Biochim. Biophys. Acta 1998, 1400, 139-154.

31. Liu, L.F. DNA topoisomerase poisons as antitumor drugs. Annu. Rev. Biochem. 1989, 58, 351-375.

32. Chakraborty, A.K.; Majumder, H.K. Mode of action of pentavalent antimonials: specific inhibition of type I DNA topoisomerase of Leishmania donovani. Biochem. Biophys. Res. Commun. 1988, 152, 605-611.

33. Ray, S.; Hazra, B.; Mittra, B.; Das, A.; Majumder, H.K. Diospyrin, a bisnaphthoquinone: a novel inhibitor of type I DNA topoisomerase of Leishmania donovani. Mol. Pharmacol. 1998, 54, 994999.

34. Mosmann, T. Rapid colorimetric assay for cellular growth and survival: application to proliferation and cytotoxicity assays. J. Immunol. Methods 1983, 65, 55-63.

35. Murakami-Nakai, C.; Maeda, N.; Yonezawa, Y.; Kuriyama, I.; Kamisuki. S.; Takahashi, S.; Sugawara, F.; Yoshida, H.; Sakaguchi, K.; Mizushina, Y. The effects of dehydroaltenusin, a novel mammalian DNA polymerase $\alpha$ inhibitor, on cell proliferation and cell cycle progression. Biochim. Biophys. Acta 2004, 1674, 193-199.

36. Nishida, K.; Seto, M.; Ishida, R. Different susceptibilities of postmitotic checkpoint-proficient and -deficient Balb/3T3 cells to ICRF-193, a catalytic inhibitor of DNA topoisomerase II. Jpn. J. Cancer Res. 2001, 92, 193-202.

37. Woo, R.A.; Poon, R.Y. Cyclin-dependent kinases and S phase control in mammalian cells. Cell Cycle 2003, 2, 316-324.

38. Pines, J.; Hunter, T. Isolation of a human cyclin cDNA: evidence for cyclin mRNA and protein regulation in the cell cycle and for interaction with p34 cdc2. Cell 1989, 58, 833-846.

39. Byun, T.S.; Pacek, M.; Yee, M.C.; Walter, J.C.; Cimprich, K.A. Functional uncoupling of MCM helicase and DNA polymerase activities activates the ATR-dependent checkpoint. Genes. Dev. 2005, 19, 1040-1052. 
40. Rittling, S.R.; Brooks, K.M.; Cristofalo, V.J.; Baserga, R. Expression of cell cycle-dependent genes in young and senescent WI-38 fibroblasts. Proc. Natl. Acad. Sci. U.S.A. 1986, 83, 33163320 .

41. Matsushime, H.; Ewen, M.E.; Strom, D.K.; Kato, J.Y.; Hanks, S.K.; Roussel, M.F.; Sherr, C.J. Identification and properties of a typecal catalytic subunit (p34PSK-J3/cdk4) for mammalian D type G1 cyclins. Cell 1992, 71, 323-334.

42. Meyerson, M.; Harlow, E. Identification of G1 kinase activity for cdk6, a novel cyclin D partner. Mol. Cell. Biol. 1994, 14, 2077-2086.

43. Hunter, T.; Pines, J. Cyclins and cancer. II: Cyclin D and CDK inhibitors come of age. Cell 1994, 79, 573-582.

44. Toyoshima, H.; Hunter, T. p27, a novel inhibitor of G1 cyclin-Cdk protein kinase activity, is related to $\mathrm{p} 21$. Cell 1994, 78, 67-74.

45. Xiong, Y.; Hannon, G.J.; Zhang, H.; Casso, D.; Kobayashi, R.; Beach, D. p21 is a universal inhibitor of cyclin kinases. Nature 1993, 366, 701-704.

46. Falck, J.; Mailand, N.; Syljuasen, R.G.; Bartek, J.; Lukas, J. The ATM-Chk2-Cdc25A checkpoint pathway guards against radioresistant DNA symtnesis. Nature 2001, 410, 842-847.

47. Galaktionov, K.; Beach, D. Specific activation of cdc25 tyrosine phosphatase by B-type cyclins: evidence for multiple roles of mitotic cyclins. Cell 1991, 67, 1181-1194.

48. Blomberg, I.; Hoffmann, I. Ectopic expression of Cdc25A accelerates the $G(1) / S$ transition and leads to premature activation of cyclin E- and cyclin A-dependent kinases. Mol. Cell. Biol. 1999, 19, 6183-6194.

49. Sandhu, C.; Donovan, J.; Bhattacharya, N.; Stampfer, M.; Worland, P.; Slingerland, J. Reduction of Cdc25A contributes to cyclin E1-Cdk2 inhibition at senescence in human mammary epithelial cells. Oncogene 2000, 19, 5314-5323.

50. Zou, L.; Elledge, S.J. Sensing DNA damage through ATRIP recognition of RPA-ssDNA complexes. Science 2003, 300, 1542-1548.

51. Melo, J.; Toczyski, D. A unified view of the DNA-damage checkpoint. Curr. Opin. Cell Biol. 2002, 14, 237-245.

52. Yonezawa, Y.; Tsuzuki, T.; Eitsuka, T.; Miyazawa, T.; Hada, T.; Uryu, K.; Murakami-Nakai, C.; Ikawa, H.; Kuriyama, I.; Takemura, M.; Oshige, M.; Yoshida, H.; Sakaguchi, K.; Mizushina, Y. Inhibitory effect of conjugated eicosapentaenoic acid on human DNA topoisomerases I and II. Arch. Biochem. Biophys. 2005, 435, 197-206.

53. Yonezawa, Y.; Hada, T.; Uryu, K.; Tsuzuki, T.; Eitsuka, T.; Miyazawa, T.; Murakami-Nakai, C.; Yoshida, H.; Mizushina, Y. Inhibitory effect of conjugated eicosapentaenoic acid on mammalian DNA polymerase and topoisomerase activities and human cancer cell proliferation. Biochem. Pharmacol. 2005, 70, 453-460.

54. Yonezawa, Y.; Hada, T.; Uryu, K.; Tsuzuki, T.; Nakagawa, K.; Miyazawa, T.; Yoshida, H.; Mizushina, Y. Mechanism of cell cycle arrest and apoptosis induction by conjugated eicosapentaenoic acid, which is a mammalian DNA polymerase and topoisomerase inhibitor. Int. J. Oncol. 2007, 30, 1197-1204.

55. Sahara, H.; Hanashima, S.; Yamazaki, T.; Takahashi, S.; Sugawara, F.; Ohtani, S.; Ishikawa, M.; Mizushina, Y.; Ohta, K.; Shimozawa, K.; Gasa, S.; Jimbow, K.; Sakaguchi, K.; Sato, N.; 
Takahashi, N. Anti-tumor effect of chemically synthesized sulfolipids based on sea urchin's natural sulfonoquinovosylmonoacylglycerols. Jpn. J. Cancer Res. 2002, 93, 85-92.

56. Sakaguchi, K.; Sugawara, F.; Mizushina, Y. Inhibitors of eukaryotic DNA polymerases. Seikagaku 2002, 74, 244-251.

(C) 2007 by MDPI (http://www.mdpi.org). Reproduction is permitted for noncommercial purposes. 